\title{
I WANT MY MTV, WE WANT OUR TMF
}

\section{THE MUSIC FACTORY, MTV EUROPE, AND MUSIC TELEVISION IN THE NETHERLANDS, $1995-2011$}

\author{
Jaap Kooijman \\ Media Studies \\ University of Amsterdam \\ Turfdraagsterpad 9 \\ 1012 XT Amsterdam \\ The Netherlands \\ J.W.Kooijman@uva.nl
}

\begin{abstract}
The Dutch music television channel, The Music Factory (TMF), launched in 1995, presented a local alternative to MTV Europe, owned by the US-based conglomerate, Viacom. In 2001, Viacom took over TMF, which by then proved to be far more popular than MTV Europe among young Dutch viewers, and for three years, turned TMF into a text-message-based "interactive" music television channel. In 2011, Viacom discontinued the TMF brand. This article places the relatively short history of TMF within the contexts of the emergence of commercial television in Europe and the shift of music videos from television to other media platforms, as well as broader discussions of globalisation.
\end{abstract}

Keywords: music television, globalisation, interactive television, absolute fake

\section{Introduction}

Launched in May 1995 by the Arcade Media Group, The Music Factory (TMF) was one of the first Dutch commercial television channels. ${ }^{1}$ Initially, the music television channel was met with scepticism by the press. One journalist deemed TMF "very low, low, low budget television," recognizing MTV Europe in comparison as "an oasis of creativity, variety, and originality," whereas another, echoing the Coca-Cola slogan, predicted that Dutch teenagers would prefer "the real thing" to TMF. ${ }^{2}$ History proved them wrong. In 2000, an audience reception study by scholars from the Communication Science department of the University of Nijmegen showed that TMF was far more popular than MTV among Dutch youth, suggesting "that TMF has been able to adjust better to local conditions and that its programming 
is better suited to the local target groups than MTV's." ${ }^{3}$ In response to TMF's popularity, MTV (part of the US-based conglomerate, Viacom) launched MTV NL in 2000, specifically targeting Dutch viewers. One year later, MTV took over TMF, transforming its former competitor into a text-message-based "interactive" music television channel, while moving most of TMF's programs and veejays to MTV NL. As MTV CEO, Dan Ligtvoet, admitted, a takeover was the most logical strategy, stating, "If you can't beat them, buy them." In 2011, Viacom discontinued the TMF brand in the Netherlands (and four years later in Belgium), replacing TMF with Comedy Central.

The relatively short history of TMF is part of four transformations that have occurred since the 1980s in both European television and global music television. First, the 1989 "Television Without Frontiers" EU directive enabled the deregulation of the European television market from nationally based public broadcasting to mixed systems of public and commercial television, as well as the emergence of transnational television channels distributed through cable and satellite. ${ }^{5}$ Second, with the launch of MTV Europe and MTV Australia in 1987, MTV expanded from a single US American cable channel to a global television network. ${ }^{6}$ Third, MTV's programming moved from predominantly music videos to non-music long-form content (reality television, drama, and comedy), a shift that was emphasized when MTV dropped the words "Music Television" from its logo in 2010.7 Fourth, the dominant form of distributing and viewing music videos moved from analogue and linear music television to digital media platforms, including Internet channels such as YouTube and VEVO. ${ }^{8}$

In addition to these four transformations, TMF can be considered a case study of Americanisation and globalisation. As I have discussed in more detail elsewhere, the global circulation of US American culture-particularly Hollywood, television, pop music, and advertising -is often perceived from two seemingly contradicting perspectives: either as cultural imperialism in which local cultures are taken over by US American culture or as cultural appropriation in which local cultures actively adapt and translate US American culture within their own specific contexts. ${ }^{9}$ George Ritzer's "grobalisation" and Roland Robertson's "glocalisation" are two useful concepts to interpret this distinction. Grobalisation emphasises the capitalist expansionist character of globalisation, as transnational conglomerates, in search of profit and economic growth, have turned the world into one global market, resulting in global homogeneity. Glocalisation, on the contrary, emphasises how this global mass culture is actively appropriated at the local level, resulting in global heterogeneity. ${ }^{10}$ Although seemingly contradictory, these two perspectives actually reinforce each other. The strength of global yet US American-style capitalism is its ability to incorporate different forms of popular culture that are widely attractive to consumers in various countries and regions. As Stuart Hall has argued, US-based globalisation does not aim to replace different local cultures around the world with US American culture, but instead "is wanting to recognize and absorb those differences within the larger, overarching framework of what is essentially an American conception of the world." 11 Hall's perspective is productive to understand TMF as a local pop culture that has successfully appropriated US American pop culture by adapting its form rather than its culturally-specific content, only

3 Gerrit A.J. van der Rijt, Gerrit A.J., Leen S.J. d'Haenens, Ronald H.A. Jansen, and Cor J. de Vos, 'Young People and Music Television in the Netherlands,' European Journal of Communication, 15, 1, 2000, 79-91.

4 Hans van der Beek, 'Onderste balk is voor kijker: "Het mag wel commercieel zijn, maar niet nep of gemaakt",' Het Parool, 10 January 2004.

5 Jean K. Chalaby, Transnational Television in Europe: Reconfiguring Global Communications Networks, I.B. Tauris, 2009.

6 Saul Austerlitz, Money For Nothing: A History of the Music Video from the Bealtes to the White Stripes, Continuum, 2007; Andrew Goodwin, Dancing in the Distraction Factory: Music Television and Popular Culture, University of Minnesota Press, 1992; Jack Banks, Monopoly Television: MTV's Quest to Control the Music, Westview Press, 1996; Craig Marks and Rob Tannenbaum, I Want My MTV: The Uncensored Story of the Music Video Revolution, Dutton, 2011.

7 Steve Jones, 'MTV: The Medium was the Message,' Critical Studies in Media Communication, 22, 1, 2005, 83-88.

8 Roger Beebe and Jason Middleton, eds, Medium Cool: Music Videos from Soundies to Cellphones, Duke University Press, 2007; Henry Keazor and Thorsten Wübbena, eds, Rewind, Play, Fast Forward: The Past, Present and Future of the Music Video, transcript, 2010; Carol Vernallis, Unruly Media: YouTube, Music Video, and the New Digital Cinema, Oxford University Press, 2013.

9 Jaap Kooijman, Fabricating the Absolute Fake: America in Contemporary Pop Culture, revised and extended edition, Amsterdam University Press, 2013, pp. 13-17

10 George Ritzer, The McDonaldization of Society: Revised New Century Edition, Pine Forge Press, 2004; Roland Robertson, Globalization: Social theory and global culture, Sage, 1992.

11 Stuart Hall, 'The Local and the Global: Globalization and Ethnicity,' in Antony D. King, ed, Culture, Globalization, and the World-System, University of Minnesota Press, 1997, p. 28. 
to end up being incorporated within the global network of the US-based MTV. In other words, TMF is an example of both grobalisation and glocalisation - a music television channel that is part of MTV's global expansion while adapting and translating US American pop culture within a specific Dutch national context.

\section{MTV Europe: "One PIanet-One Music"}

With the notable exception of the attention given to the German music television channel, VIVA (which was launched in 1993 and then, similar to TMF, was taken over by Viacom in 2005), academic studies on music television predominantly focus on the US and the UK, and in particular, on MTV. ${ }^{12}$ Music videos existed before the launch of the US American channel MTV in 1981; in fact, most music videos initially shown on MTV came from the UK due to a lack of US American content. ${ }^{13}$ However, as Andrew Goodwin argues in his pivotal 1992 study, Dancing in the Distraction Factory, MTV came to define music television because of "its intrinsic qualities as a different kind of television," both in its aesthetic form and its targeted audience. ${ }^{14}$ MTV presented a 24-hour rapid-montage stream of music videos interspersed with commercials, resulting in the so-called "MTV aesthetic," a continuous flow of sound and image that many, most notably E. Ann Kaplan, perceived as an embodiment of postmodern culture. ${ }^{15}$ Both Goodwin and Kaplan point out the importance of MTV's commercial character of selling a fashionable lifestyle through pop music that speaks to a niche audience of young adults in the aim of attracting advertisers interested in targeting that specific demographic. ${ }^{16}$

On August 1, 1987, exactly six years after the start of MTV in the US, MTV Europe was launched with a live event at the Amsterdam dance club, RoXY (which officially would open its doors the following evening), with British pop star, Elton John, pulling the switch that launched the broadcast of MTV Europe's first music video: "Money For Nothing" by the Dire Straits, which included the original MTV slogan "I Want My MTV" sung repeatedly by Sting. That the event was held in Amsterdam rather than London, where MTV Europe's head office and studios were located, highlighted MTV's aim to reach continental Europe. Compared to other European countries, including the UK, the Netherlands, together with Belgium, had the most households with cable access to MTV, even in absolute numbers. ${ }^{17}$ Before MTV Europe, music videos in the Netherlands were featured in weekly pop music programs on public broadcasters such as TopPop (AVRO, 1970-1988), Countdown (Veronica, 1976-1993), and Popformule (TROS, 1984-1991). Viewers with cable access could also watch music videos on the pan-European channels, Music Box (1984-1987), Super Channel (1987-1988), and Sky Channel (1983-1989), the former a 24-hour music television channel and the latter two featuring pop music programs such as the international edition of Countdown (1987-1989) and Linda de Mol's The DJ Kat Show (1986-1989). However, none of these programs and channels had the explicit connection to the MTV brand that had become synonymous with music television.

Similar to its US counterpart, MTV Europe predominantly showed music videos by American and British pop artists, including Michael Jackson, Madonna, David Bowie, and George Michael. Unlike the pop music programs produced by the national public broadcasters, MTV Europe did not offer room for continental European pop artists. ${ }^{18}$ In his

12 Ulrich Adelt, 'Ich bin der Rock'n'Roll-Übermensch': Globalization and Localization in German Music Television,' Popular Music and Society, 28, 3, 2005, 279-295; Axel Schmidt, Klaus Neumann-Braun, and Ulla Autenrieth, Viva MTV! Reloaded: Musikfernsehen und Videoclips Crossmedial, Nomos, 2009.

13 Austerlitz, Money for Nothing, 2007, p. 32; Marks and Tannenbaum, I Want My MTV, 2011, p. 113.

14 Goodwin, Dancing in the Distraction Factory, 1992, p. xxvii.

15 E. Ann Kaplan, Rocking Around the Clock: Music, Television, Postmodernism and Consumer Culture, Methuen, 1987.

16 Goodwin, Dancing in the Distraction Factory, 1992; Kaplan, Rocking Around the Clock, 1987.

17 Chalaby, Transnational Television in Europe, 2009, p. 38.

18 Keith Roe and Gust De Meyer, 'Music Television: MTV-Europe,' in Jan Wieten, Graham Murdock, and Peter Dahlgren, eds, Television Across Europe: A Comparative Introduction, Sage, 2000, 141-157; Roe and De Meyer, 'One Planet-One Music: MTV and Globalization,' in Andreas Gebesmair and Alfred Smudits, eds, Global Repertoires: Popular Music within and Beyond the Transnational Music Industry, Ashgate, 2001, pp. 3344. Initially, MTV Europe was a cooperation between Viacom and the British telecom company BT. In 1991, Viacom became the sole owner. 
study of MTV, Jack Banks defined such programming as a form of cultural imperialism: "The spotlight on US and UK acts reinforces the dominance of these acts throughout the continent, consigning indigenous artists to the margins of popular culture even within their own countries."19 Intriguingly, Simon Reynolds of The New York Times recognized a significant difference between MTV Europe and its US counterpart, arguing that MTV Europe not only was more blatantly commercial with sponsored programs such as MTV Coca-Cola Report and The Pulse With Swatch, but also "smoothed out the vitality of American MTV" by focusing too much on "middle-aged" rock acts such as Rod Stewart, Tina Turner, and David Bowie, resulting in "a homogenous [European identity for teenagers] dominated by BritishAmerican pop culture."20 In other words, MTV Europe's initial slogan "One Planet-One Music" could be interpreted as heralding MTV's grobalisation strategy, as MTV distributed a global mass pop culture that was even more commercial and mainstream than the US American "original" on which it was based.

However, as several scholars have pointed out, MTV's "One Planet-One Music" strategy turned out to be commercially less successful than anticipated. ${ }^{21}$ While the number of European households with cable access to MTV Europe increased, the ratings did not grow proportionally. By the mid-1990s, MTV Europe altered its strategy by diversifying its content, thus incorporating glocalisation within its strategy of grobalisation. The technology of digital compression enabled the localization of the MTV feed to specific regional audiences, and so, in 1997, MTV Europe was split up in four regions: MTV Central (Germany and Austria), MTV UK \& Ireland, MTV Italia, and MTV Nordic. Local veejays were hired within each region, such as the popular Dutch soap actress, Katja Schuurman, who hosted the program So90's! (1997-1999) for MTV Nordic, the region that included the Netherlands. ${ }^{22}$

Video 1. MTV Nordic 1998 promo of the So90's! program with Dutch veejay, Katja Schuurman, addressing the viewers in English. Please visit the online version of the article to watch this video.

According to Keith Roe and Gust De Meyer, "MTV did not compromise willingly with such diversity—it was not until competition from local music television stations began hitting viewing figures (and thereby advertising revenue and profits) that anything but lip-service was paid to the idea of regionalizing European services to cater for local variations." 23 Whether reluctantly or not, MTV Europe continued its regional and national diversification throughout the 2000s, eventually resulting in a wide range of national European channels, including MTV NL, which launched in 2000. Jean Chalaby recognized MTV Europe as "Europe's most localized network" among all pan-European commercial television channels (yet not in comparison to "local" music television channels such as the German VIVA, the French MCM, and the Dutch TMF), adding, "it is the local audiences who decide what they like among the genres and artists on offer." 24 As such, Chalaby presented MTV Europe as an example of glocalisation, suggesting that its content was shaped predominantly by the tastes of the local audiences. Indeed, as Roe and De Meyer show (based on research conducted in late 1998-early 1999), there were significant differences between the content of the four MTV Europe regions, reflecting different regional tastes. For example, US American "black music" (hip-hop) was far more prominent in the Central region, while the Southern region featured relatively the most "local" content (16.5\% Italian artists) ${ }^{25}$ However, in all four regions, British-American content remained dominant, suggesting that MTV's strategy of glocalisation reinforced rather than undermined its grobalisation.

19 Banks, Monopoly Television, 1996, p. 91.

20 Simon Reynolds, 'How MTV Plays Around the World,' The New York Times , 7 July 1991, http://www.nytimes.com/1991/07/07/arts/how-mtvplays-around-the-world-942091.html

21 Chalaby, Transnational Television in Europe, 2009, pp. 209-210; Roe and De Meijer, 'Music Television: MTV-Europe,' $2000,148-151$.

22 Noel van Bemmel, 'Trendy kwaliteitszender,' de Volkskrant, 8 November 1997; Jerry Goossens, 'Ik heb niks tegen MTV, begrijp me goed, maar op een gegeven moment werd het allemaal zo underground, zo zwaar,' Het Parool, 30 December 1997; Japke-D. Bouma, 'Hoe revolutionair is MTV nog?,' NRC Handelsblad, 7 March 1998.

23 Roe and De Meijer, 'Music Television: MTV-Europe,' 2000, 151.

24 Chalaby, Transnational Television in Europe, 2009, p. 232, p. 235.

25 Roe and De Meyer, 'Music Television: MTV Europe,' 2000, 153. 


\section{TMF as "Absolute Fake"}

As mentioned in the introduction, when TMF was launched in 1995, Dutch media were sceptical about the music channel's popularity among Dutch teenagers, assuming that they would favour "the real thing" MTV over a cheap imitation. ${ }^{26}$ The use of the Coca-Cola advertising slogan, "the real thing" is reminiscent of how Umberto Eco has discussed US American culture in his Travels in Hyperreality. According to Eco, US American culture consists of perfect copies of cultural artefacts that are not sheer imitations, but improved copies, and thus more "real," than their originals, meaning that they are better adapted to American usage. As Eco states, "the American imagination demands the real thing and, to attain in, must fabricate the absolute fake." ${ }^{27}$ Although Eco speaks exclusively of US American culture, in my book, Fabricating the Absolute Fake, I have applied Eco's concept to Dutch pop-cultural objects that tend to be viewed as merely imitations of US American pop culture. ${ }^{28}$ By treating these objects as absolute fakes rather than just copies, the process of cultural appropriation is rendered visible. Instead of using Eco's absolute fake as a value judgment (TMF is "fake" because it is a cheap imitation of MTV), one can perceive TMF as an absolute fake in the sense that the music television channel is a copy of MTV that may be experienced as "more real" than "the original" by Dutch viewers, because the use of Dutch language as well as the inclusion of Dutch pop artists makes the music television channel more relevant and connected to the Dutch viewers' daily experience of pop culture. To paraphrase Eco, the Dutch imagination demands the real thing (MTV) and, to attain it, must fabricate the absolute fake (TMF).

Although TMF can correctly be seen as a local alternative to MTV Europe, its founding in 1995 is not just related to MTV's global expansion, but is also rooted in the history of pop music broadcasting in the Netherlands, both on radio and television. TMF's initiator and first CEO, Lex Harding, who had been one of the deejays of the 1960s offshore "pirate" radio station Veronica, believed that music television was basically radio with moving images. ${ }^{29}$ In 1992, Harding founded the commercial radio station, Radio 538 (the name referring to Veronica's original wavelength), and an expansion into music television seemed logical. Moreover, Studio Concordia in Bussum, the home base of not only TMF but also Radio 538 and the commercial television channel, TV10 Gold (like TMF, headed by Harding), was the studio from which Veronica's pop music television program Countdown had been broadcast in previous years. In addition to the weekly national edition on public broadcaster Veronica, in 1987, a daily international edition of Countdown was produced for the pan-European Music Box channel, hosted by veejays Erik de Zwart and Adam Curry, the latter who would leave for the US to become a popular US MTV veejay $(1987-1994) \cdot{ }^{30}$ After the discontinuation of Music Box, the international Countdown was broadcast first on Super Channel and then on Sky Channel, hosted by veejay Wessel van Diepen. Firmly located in a space where music television had been produced since the 1980s, including experimentation with commercial pan-European television, TMF was a logical project to emerge, regardless of MTV Europe and its cultural dominance in European music television.

TMF's first team of eight veejays showed a significant gender divide. The four male veejays were all Radio 538 deejays - the former Countdown presenters, De Zwart and Van Diepen, joined by Ruud de Wild and Michael Pilarczyk - building on previous expertise. The new and most prominent faces of TMF, however, were four female veejays, all in their early twenties and most often referred to by their first name only: the "girl next door" Fabienne (de Vries), the "sexy blonde" Bridget (Maasland), the "soulful" Sylvana (Simons), and the "alternative rock chick" Isabelle (Brinkman). Their personalities were explicitly connected to the programs they hosted, such as Bridget on Air, Sylvana's Soul, and It's Isabelle. The most popular was undoubtedly Fabienne, whose two-hour program, Toute

26 Van Reijsen, 'Presentatrices TMF staan stijf van de angst,' Algemeen Dagblad, 7 June 1995; Walraven, 'Op tv is Music Factory niet "the real thing", 'De Gelderlander, 9 September 1995. Translation mine.

27 Umberto Eco, Travels in Hyperreality: Essays, Harcourt, Brace \& Company, 1986, pp. 7-8.

28 Kooijman, Fabricating the Absolute Fake, 2013, pp. 100-101.

29 Marco Struyk and Rene Quist, 'Radio met mooie plaatjes: Muziekzenders MTV en TMF spelen oorlogje op kleine schaal,' Algemeen Dagblad, 17 June 1996.

30 Marks and Tannenbaum, I Want My MTV, p. 370. 

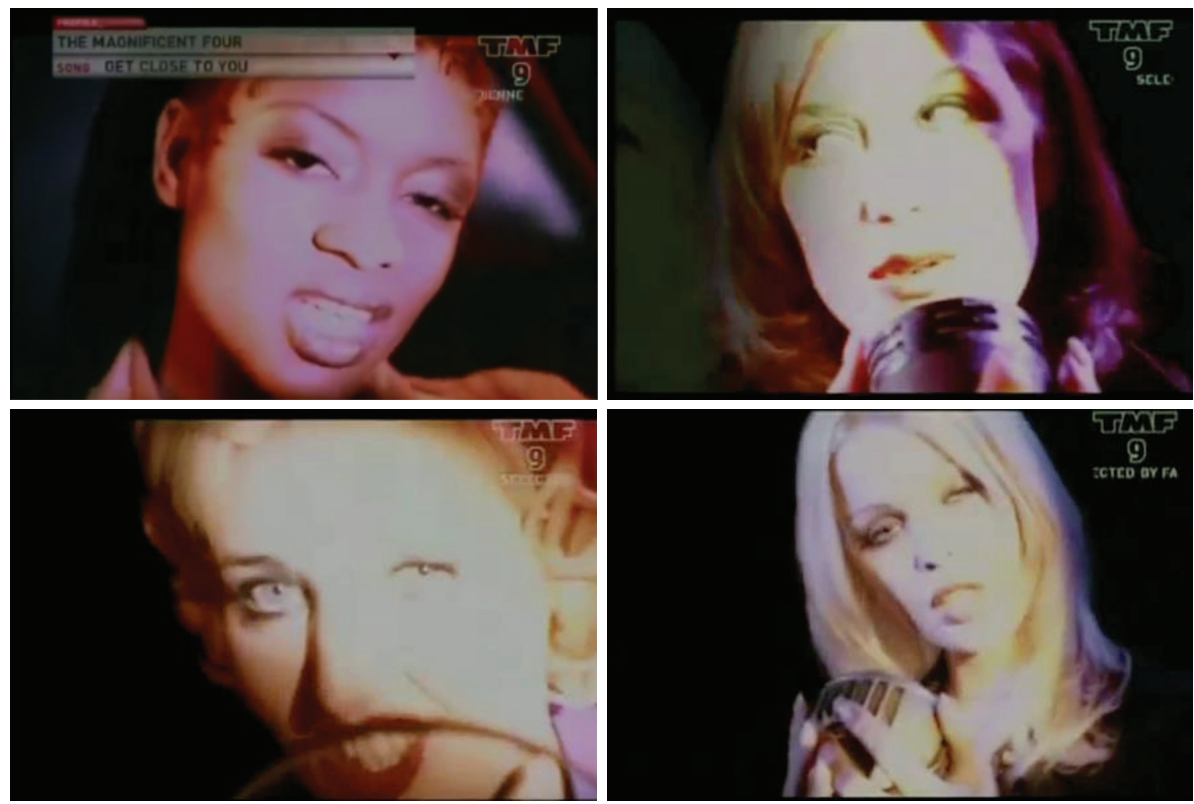

Figure 1. Four screenshots of the "Get Close To You" music video by The Magnificent Four, featuring (clockwise from top left) veejays Sylvana, Fabienne, Bridget and Isabelle.
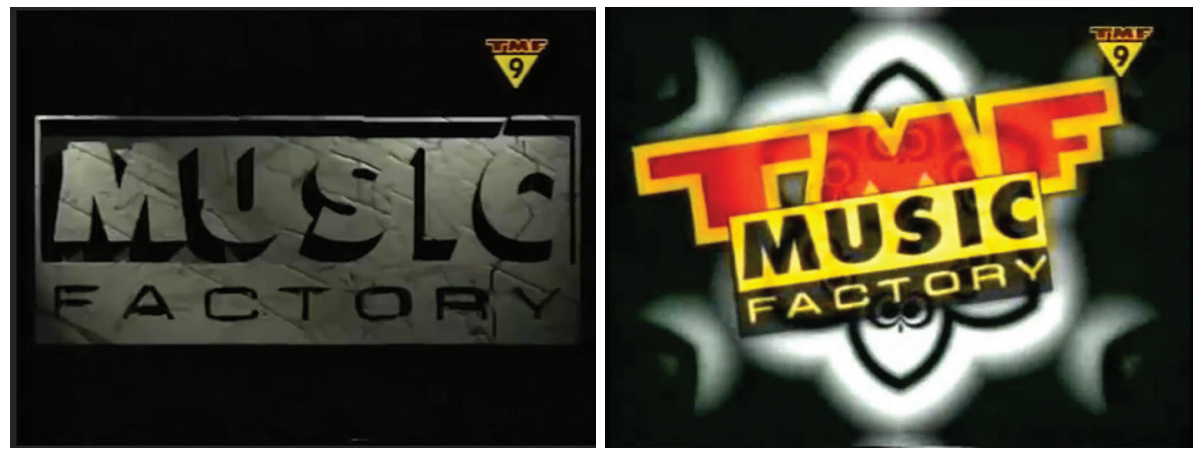

Figure 2. Two screenshots of the early TMF logos from 1996 and 1997, respectively. In both cases, the TMF acronym is used in the small channel logo at the top right of the screen; both main logos still highlight the words "Music Factory," which eventually would be dropped in favour of the TMF acronym.

Fabienne, was the only one that was broadcast live (while the others were pre-taped) every school day in the late afternoon. The four female veejays were used to promote the new channel in the Dutch media far more than their male colleagues. Moreover, inspired by the success of The Spice Girls, they formed the "girl group", The Magnificent Four (TMF), in 1997 and released the song, "Get Close To You," which became a hit single on the Dutch charts. ${ }^{31}$ The four different personalities of the female TMF veejays invited Dutch viewers to feel connected, literally "getting close to" and identify with fellow Dutch youngsters rather than with international—and thus far away—celebrity veejays.

Throughout TMF's first year of broadcast, MTV publically and repeatedly accused TMF of imitating its logo, style, and content, including TMF's use of English in naming its brand and programs, arguing that there was nothing "specifically Dutch" about the music television channel that used the slogan, "This is The Music Factory." In response, TMF's Lex Harding explained that English was the common-used language of Dutch youth culture and that 
TMF's style was based on the standard format of music television. ${ }^{32}$ Both sides made sense. That TMF was a "copy" of the "original" MTV seemed obvious; the three-letter acronym TMF, pronounced in English, was clearly inspired by the MTV logo. Yet to perceive TMF as a direct copy of MTV ignores that the MTV aesthetic was a major source in the shaping of global teenage pop culture-thus also in the Netherlands-and as such had become the dominant form of music television.

Like MTV, TMF featured pop artists from the US and the UK, yet, unlike MTV, TMF also provided space for Dutch pop artists and music genres such as "gabber house" that were popular specifically in the Netherlands. To what extent their success can be ascribed to the exposure on TMF is difficult to assess, but the late 1990s saw a significant increase in popularity of Dutch pop artists, whether they were singing in English, such as Anouk, Total Touch, and Ilse DeLange, or in Dutch, such as Marco Borsato, Guus Meeuwis, Volumia!, and BLØF. Unlike the Dutch pop artists before them and prompted by the platform provided by TMF, these artists released music videos for most of their singles. Before TMF, Dutch music videos received too little exposure to make their production profitable. As TMF's program director, Frank Helmink, pointed out in 1997: "It has been clearly demonstrated that TMF is the reason why Dutch pop acts produce a music video. Since the last two years, many more Dutch pop acts made the charts. I do believe that TMF has contributed to that." ${ }^{\text {33 }}$

Video 2. TMF 1996 promo for the pre-taped Sunday evening show, Watch That Video, hosted by veejay Fabienne; while the program title is in English, the voiceover is in Dutch. Please visit the online version of the article to watch this video.

TMF can be perceived as an absolute fake, as the music channel successfully adapted MTV's US American-based yet global format within a local context by featuring local veejays who addressed the viewers in their native language and by providing a platform for Dutch pop acts. When celebrating its tenth anniversary with a special broadcast during the first weekend of October 2005, TMF explicitly presented itself as "the original," although by then the music channel had been taken over by MTV. The TMF: The Beginning broadcast highlighted the role of Lex Harding and the four female veejays, who all had left TMF by the time of MTV's takeover in 2001 or soon thereafter. A telling example of TMF as an absolute fake is the 2005 promo of the TMF: The Beginning. Opening with a flashy animation followed by a rapid montage of archival footage of TMF's veejays and Dutch pop artists, the promo exemplifies the MTV aesthetic, yet shows Dutch content only. Most significant is the male voiceover, spoken in Dutch, calling TMF the "ultieme Nederlandse muziekkanaal" ("ultimate Dutch music channel") and inviting the viewers to find out "Hoe is de enige echte Nederlandse muziekzender TMF tot stand gekomen?" ("How did the only real Dutch music channel TMF come into existence?"). Not without irony, after being incorporated within MTV's global network, TMF could be rebranded as "the real thing" rather than as a cheap imitation of "the original" MTV.

Video 3. TMF 2005 promo of the TMF: The Beginning broadcast. Please visit the online version of the article to watch this video.

\section{TMF versus MTV Europe}

Between TMF's launch in 1995 and its takeover by MTV in 2001, the "battle" between the two music television channels was measured in ratings and popularity polls among young Dutch viewers. Based on such data, "TMF beats MTV," was a headline of a Dutch national newspaper published in August 1996. According to the newspaper, TMF attracted three times as many viewers than MTV Europe, while polls showed that a large majority of the Dutch

32 Struyk and Quist, 'Radio met mooie plaatjes,' Algemeen Dagblad, 17 June 1996; Noel van Bemmel, 'Er zit geen muziek meer in MTV,' NRC Handelsblad, 1 August 1996.

33 Goossens, 'Ik heb niks tegen MTV, begrijp me goed, maar op een gegeven moment werd het allemaal zo underground, zo zwaar,' Het Parool, 30 December 1997. Translation mine. 
youth preferred TMF to MTV. ${ }^{34}$ However, the battle was not just about popularity through attracting viewers but also about getting access to cable. Although in absolute numbers the Netherlands and Belgium had the most households with a cable television connection within Europe, actual space on cable was limited. The decision of which television channels to include differed from one municipality to another and often depended on local politics. In most cases, one music television channel was deemed sufficient, resulting in a choice between TMF and MTV. This placed the two channels in a contradictory position. On the one hand, TMF and MTV Europe were competitors trying to convince local politicians that the one was more popular than the other among young Dutch viewers. Both channels launched local advertising campaigns and organised live music events to increase their popularity. On the other hand, TMF and MTV Europe had a shared interest in showing that the two music television channels actually were complementary to each other. Instead of replacing MTV with TMF, or vice versa, local governments could make room for both music television channels by excluding other television channels—such as the German RTL or the Italian Rai 1—from the local cable offering.

To make matters even more complicated, in 1995, MTV Europe had announced that the channel was planning to start demanding a transmission fee, as was common in many other countries, but not yet in the Netherlands. Although MTV Europe quickly retracted its plans, for many Dutch municipalities the announcement was reason enough to replace MTV with TMF. One prominent example is the city of Tilburg, where the exclusion of MTV Europe resulted in a two-year political battle, largely prompted by local protests movements organised on both sides. Pop music professionals in Tilburg, including the managers of concert venues and record stores, feared that the disappearance of MTV would hurt the city's aspiration to become an internationally acclaimed "pop cluster"-in 1998, the large pop concert venue 013 was opened, as well as the first national Rock Academy of the Fontys University of Applied Sciences. As the protesters argued, without MTV, Tilburg could no longer aspire to be an international centre of serious pop music. When, one year later, the city government decided to switch from TMF back to MTV Europe, another civilian protest started, this time in favour of keeping TMF. The Tilburg-based pop star, Guus Meeuwis, was the movement's best known spokesperson, arguing that Dutch pop music needed a "strong national music channel" to be successful. Eventually, the city of Tilburg decided that having two pop music television channels would be the most preferable. ${ }^{35}$

Whereas in Tilburg the choice between TMF and MTV Europe was a matter of local politics, in The Hague the battle between the two music television channels, as well as the cable company Casema, was fought out in court with a two-year series of summary proceedings between 1995 and 1997. At first, the court decided in favour of TMF, but the decision was soon overruled. Instead, Casema was ordered to conduct a questionnaire among viewers between 16 and 34 years old to let the viewers decide which channel should be made available. After an elaborate promotion campaign by both TMF and MTV Europe, the outcome was in favour of MTV Europe, which was challenged unsuccessfully by TMF in court. One year later, however, the tables were turned when a new questionnaire suggested that TMF was the most popular and, in September 1997, MTV Europe was replaced by TMF, this time unsuccessfully challenged by MTV Europe. Almost unnoticed in the media, MTV Europe returned to the cable in The Hague one year later in September 1998, yet without replacing TMF. ${ }^{36}$ Similar to Tilburg, The Hague now had room for two music television channels on its cable network, raising the question why such an extensive legal battle had been necessary at all.

34 'TMF wint van MTV,' Algemeen Dagblad, 27 August 1996.

35 'Mogelijk terugkeer van populaire muziekzender; Politiek gevoelig voor MTV-acties,' Brabants Dagblad, 24 August $1995 ;$;B\&W willen MTV niet terug op de kabel,' Brabants Dagblad, 6 September 1995; Eric Boehm, 'Tilburgs offensief van The Music Factory,' Brabants Dagblad, 8 May1996; 'MTV hoeft tot '98 geen geld van kabel Tilburg,' Brabants Dagblad, 9 May 1996; 'Handtekeningen voor behoud TMF in Tilburg,' Brabants Dagblad, 28 May1996; 'MTV schermt met popcluster in strijd CAI Tilburg,' Brabants Dagblad, 30 May 1996; 'Tilburgse politiek wil twee popzenders,' Brabants Dagblad, 11 June 1996.

36 'The Music Factory wint strijd met kabelexploitant,' ANP, 14 November 1995; 'Verkiezingsoorlog om Haagse televisie-zenders,' Algemeen Dagblad, 11 January 1996. 'Haagse kijker laat Music Factory vallen,' Trouw, 30 January 1996. 'MTV moet op Haagse kabel wijken voor TMF,' NRC Handelsblad, 1 July 1997; 'MTV terug in Den Haag,' Algemeen Dagblad, 28 August 1998. 
What stands out in the battles between TMF and MTV Europe is that both channels seemed to agree on what made the one significantly different than the other. Instead of a distinction along the lines of nationality (Dutch versus American, local versus global), the emphasis was placed on the difference of targeted audience and musical taste. TMF presented itself as a "Top 40 music" (the Dutch term for mainstream commercial pop) channel aimed at teenagers, who not only watched their favourite music videos, but also attended the annual TMF Awards and bought the TMF merchandise, such as the TMF school diaries, the "Hits Made Famous by The Music Factory" compilation CDs, and the TMF clothing line. MTV Europe, on the contrary, presented itself as a "quality" music channel aimed at young adults in their twenties who preferred alternative rock and hip-hop to commercial pop music. ${ }^{37}$ Both channels highlighted this distinction to show that they were complementary to-rather than competing with—each other. Moreover, the media eagerly repeated the distinction. In a 1997 newspaper article based on interviews with both TMF and MTV Europe producers, journalist Jerry Goossens concluded:

MTV tries to elevate its audience by interrupting the flow of music videos with short art films, or with socially relevant topics such as AIDS, human rights, and the environment. TMF, in contrast, presents 24 hours of happiness and fun. The channel has no other pretention than to please the viewer as much as possible. ${ }^{38}$

Such a distinction between "alternative" MTV versus "commercial" TMF may be compelling, but is too simplistic for two reasons. First, as the aforementioned audience reception study from the University of Nijmegen suggested, the preference for one channel over the other was based mostly on subcultural differences: "TMF programming fits the youth subcultures of the 'gabbers' and the hip-hoppers. The subcultures that are best served by MTV are those whose members like rock music: punk, alto, metal and skater." ${ }^{\prime 9}$ Second, there was a great overlap in content, as both channels, aside of the subcultural emphasis, played the most recent hit music videos. Moreover, when MTV took over TMF in 2001, most of the TMF programs and veejays moved to MTV NL, showing that the "commercial" TMF could easily be incorporated within the "alternative" MTV. In the end, both TMF and MTV aimed to attract young Dutch viewers who could be targeted by advertisers, regardless of whether they preferred "commercial" or "alternative" pop music. In that sense, the battle between TMF and MTV was not between the local and the global, let alone between commercial and alternative pop culture, but a process that shows, to return to Stuart Hall's argument, how local differences are "absorbed" by the overarching global pop music television industry. ${ }^{40}$

\section{TMF as "Interactive" Television}

To lament about the lack of music videos on MTV has become a popular practice by both regular viewers and media scholars over the last two decades. ${ }^{41}$ Reality television seems to have replaced music television, as was aptly captured by the title of Robbie Williams' 2009 album Reality Killed the Video Star, an obvious reference to "Video Killed the Radio Star" by The Buggles, the first music video broadcast on the American MTV channel in $1981 .{ }^{42}$ In their introduction to Medium Cool, Roger Beebe and Jason Middleton agree that "MTV has increasingly focused on the TV over the M," but deny that this heralds the end of the music video. Though it is quite the

\footnotetext{
37 Struyk and Quist, 'Radio met mooie plaatjes,' Algemeen Dagblad, 17 June 1996; Noel van Bemmel, 'Kwaliteitszender,' de Volkskrant, 8 November 1997

38 Goossens, 'Ik heb niks tegen MTV, begrijp me goed, maar op een gegeven moment werd het allemaal zo underground, zo zwaar,' Het Parool, December 30, 1997. Translation mine.

39 Van der Rijt, et al., 'Young People and Music Television in the Netherlands,' 2000, 79.

40 Hall, 'The Local and the Global,' 1997, 28.

41 Jones, 'MTV: The Medium was the Message,' 2005, 83-88.

42 Trevor Horn, singer of "Video Killed the Radio Star," was also the producer of Robbie Williams' album Reality Killed the Video Star.
} 
contrary: not only has the number of digital music television channels increased, serving a wide range of niche audiences, the music video also has moved to other digital media platforms. As Beebe and Middleton conclude, because of these new forms of distribution, "the music video has in actuality concurrently enjoyed a major renaissance." ${ }^{43}$

When TMF was taken over by MTV in 2001, Viacom decided to turn TMF into an "interactive" music television channel, moving most of TMF's non-music video content to MTV NL. Here, two different yet related transformations come together. First, MTV NL became exemplary of the shift from music television to non-music long-form programming. As Steve Jones has pointed out, MTV's original business model of targeting a young audience to attract advertisers still worked; the only change was that such targeting was done with more effective content, such as reality television. ${ }^{44}$ Second, the new "interactive" TMF anticipated the shift from the music video on analogue television to multi-medial platforms. Although returning to the original form of music television consisting of a continuous flow of music videos interspersed with commercials, a new layer was added in the form of a text bar at the bottom of the screen. In this way, a connection was made between the television, personal computer, and mobile phone. Viewers could make a personal profile on the TMF website (including a profile picture) and become active in the online "TMF Community" consisting of personal webpages and chat boxes. Using the online ID, viewers could send SMS messages, which would be shown on the television screen after been checked by a TMF chat moderator. TMF introduced new programs that invited active contributions by the viewers, such as CyberChoice, enabling viewers to request music videos and SMS Photo Chat, enabling viewers to comment on the music video or discuss other relevant topics, with the comments shown on the text bar. ${ }^{45}$ Three different "interactive" programs are presented below by screenshots, all from October 1, 2003.46

As TMF content director, Joris van Heukelom, admitted in 2002, TMF was not really "interactive" (which technologically was not possible yet with an analogue linear television channel), but did provide its viewers "the perception of interactivity." ${ }^{17}$ Although the TMF online community, with 160,000 registered profiles, was active, in the end the TMF producers decided what was shown on screen. However, TMF's three-year experimentation with interactivity did result in provocative television. For example, when on November 2, 2004, the MoroccanDutch, Mohammed B., assassinated the controversial Dutch film director, Theo van Gogh,, TMF did not show music videos, but instead-from 3 to 8 pm-featured a black-and-white photograph of Van Gogh, accompanied by "appropriate music." Viewers were invited to text their thoughts and comments, without having to pay the usual charge, which were then shown on screen. According to TMF, the channel received 50,000 text messages. The result was a stream of televised comments that not only expressed grief and condolences, but also critically addressed ethnic relations in the Netherlands. ${ }^{48}$

TMF's experimentation with interactivity lasted only for three years. In 2005, Viacom reorganized the Dutch channels and moved some of the veejays and lifestyle programs back to TMF, thereby making the distinction in content between TMF and MTV NL less clear-cut. In addition, three new TMF digital channels were introduced: TMF Pure, TMF NL, and TMF Party. Perhaps coincidently, 2005 was also the year when the internet channel, YouTube, was launched and when Viacom took over the German music video channel, VIVA. In his book, What Makes Business Rock, US American MTV CEO, Bill Roedy, compares Viacom's take-over of VIVA to TMF, explaining

43 Beebe and Middleton, eds, Medium Cool, 2007, p. 1.

44 Jones, 'MTV: The Medium was the Message,' 2005, 87.

45 Els Oostveen, 'Interactieve muziektelevisie: De twee lagen van TMF,' MA Thesis, University of Amsterdam, 2003. In 2002, my student Oostveen did an internship at TMF, working as a chat operator, which informed her MA thesis.

46 The archives of the Netherlands Institute for Sound and Vision include several full-day broadcasts of TMF, taped twice a year between 2000 and 2010 .

47 Louis Hoeks and Bas Vlugt, 'TMF: Komende drie jaar geen interactieve digitale TV,' Emerce, 22 November 2002, http://www.emerce.nl/ nieuws/tmf-komende-drie-jaar-geen-interactieve-digitale-tv

48 'Urenlang geen clips op TMF wegens moord,' ANP, 2 November 2004; Bewust in beeld: Over media, jongeren en maatschappij, MTV Networks Benelux, 2006. Unfortunately, I have not been able to locate footage of the broadcast in the archives of the Netherlands Institute for Sound and

Vision or anywhere else. 

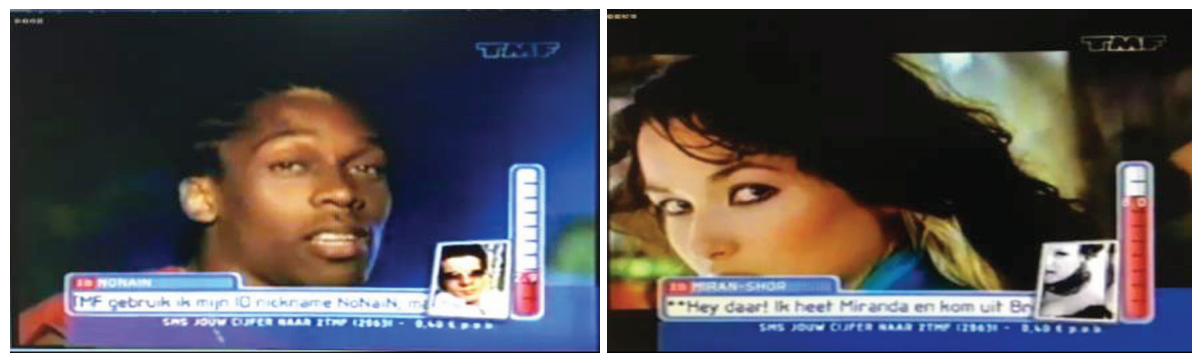

Figure 3. The daily program, Face To Face (11:30 am to noon), offered TMF ID members space to present themselves for three minutes with a personal message, their personal favourites, and their profile picture on the scrolling text bar. Underneath the text bar, viewers were invited to rate the featured TMF ID member on a scale of 1 to 10 by sending a SMS message, with the average score showing on the "thermometer" on the right side of the screen. Left: Niels (TMF ID nickname "NoNaiN") and music video "Dance (With U)" by British singer, Lemar. Right: Miranda (TMF ID nickname "Miran-Shor") and music video "Everybody Wants To Be" by Dutch singer, Bridget.
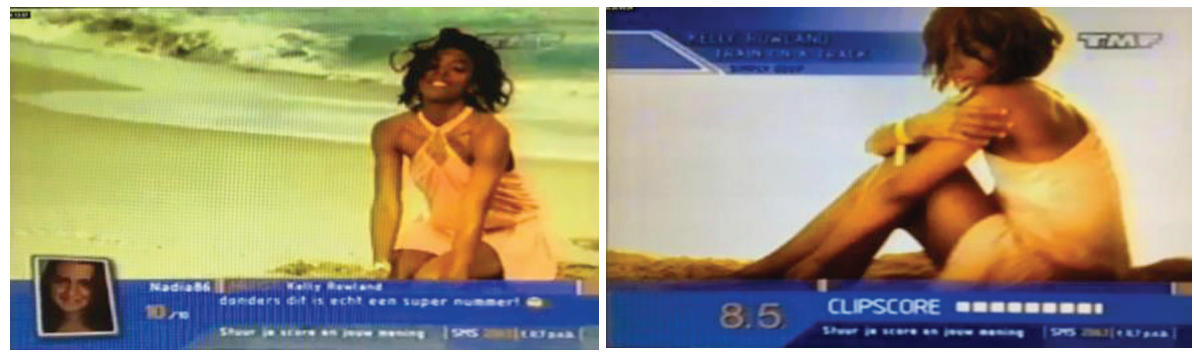

Figure 4. The daily show, Rate That Video (3 to 4 pm), invited viewers-literally — to rate and comment on the music video that was playing, with some of the comments showing on the text bar and the final score announced at the end of the music video. Left: Viewer "Nadia86" gives a 10/10 perfect score to the music video "Train On A Track" by US American singer Kelly Rowland, commenting "Damn, that is really a super song!" Right: The final "clip score" of Rowland's music video is 8.5 out of 10 .
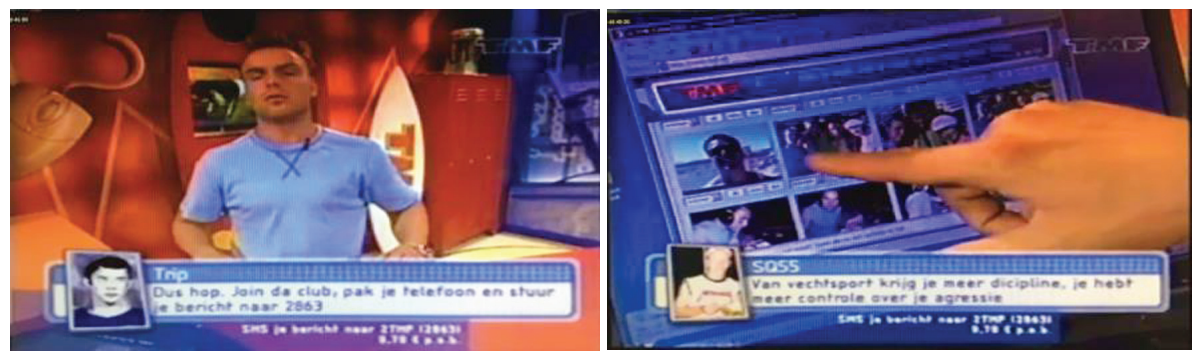

Figure 5. During the TMF "interactive" era, the daily show, Play (4 to $6 \mathrm{pm}$ ), was the only program that featured a live veejay. Left: Veejay Jeroen Post tells the viewers how to create a TMF ID account, while chat moderator, Trip, invites them to join the conversation via SMS. Right: Jeroen shows the viewers his own ID page on the TMF Community website, while TMF ID member "SQ55" refers to an earlier chat conversation about martial arts in the text bar below.

that Viacom not only bought VIVA to incorporate its main competitor in music television, but also because one of VIVA's television channels could be transformed into the German version of Nickelodeon, a children's channel also owned by Viacom. ${ }^{49} \mathrm{~A}$ similar move could be detected in the Netherlands. Music television was transferred to digital channels, thereby making room for non-music long-form television programming. What the experience of TMF with interactive television had shown was that the future of music television was not to be found in linear television, but instead in the digital realm. 


\section{Conclusion}

In November 2010, when Viacom announced that TMF would become a digital television channel only, most Dutch media interpreted this as the end of TMF. ${ }^{50}$ In an interview with the newspaper, NRC Handelsblad, I, as a media scholar, claimed that this assumption was based on a misunderstanding, relying on the Viacom press release that emphasized the company's intention to transform TMF into a strong digital brand. ${ }^{51}$ It made sense that TMF's space on cable television would be taken over by Comedy Central, as music television had moved beyond linear television. Yet TMF was still a popular brand that could attract a young audience, as was shown by the success of the annual TMF Awards, of which the last one was held in Amsterdam in 2011. In interviews, Dutch MTV CEO, Niels Baas, expressed the intention to make "TMF the youth channel of the future, a digital jukebox where you can make your own playlist at home." 52 This time, however, history proved the Dutch media right. In August 2011, Viacom announced that not only would the TMF linear television channel would be discontinued, but all its digital channels would be discontinued as well, which meant the end of TMF.

As a local alternative to the dominance of British-American pop culture, TMF can be perceived as an absolute fake, in the sense that the Dutch music television channel adapted the form of the US American original MTV to provide a platform for national, culturally-specific content that was better suited to the tastes of its Dutch young viewers. TMF's takeover by its competitor, MTV, fits the perspective of US-based globalisation that recognizes and absorbs cultural differences within an overarching global corporate network. This process is related to the transformation of European commercial television, in which pan-European networks like MTV adapted a strategy of glocalisation by regionalising and localising its content to remain popular among its viewers and secure advertising revenue. However, the eventual discontinuation of TMF was not so much based on these processes of grobalisation and glocalisation, but on the transformation in the distribution of the music videos from analogue linear television to other media platforms. Unlike MTV, which successfully made the shift to non-music long-form television programming, TMF remained predominantly a music television channel. When music videos moved to the digital realm, Viacom's main interest in TMF was the space that came available on the cable. In the end, MTV may be "the real thing," but TMF will go down in history as the only "real" Dutch music television channel.

\section{B i o graphy}

Jaap Kooijman is an associate professor in Media Studies and American Studies at the University of Amsterdam. His articles on American pop culture have been published in journals such as The Velvet Light Trap, The Journal of American Culture, Post Script, GLQ, Celebrity Studies, and [in]Transition: Journal of Videographic Film \& Moving Image Studies, as well as in edited collections including Revisiting Star Studies (Edinburgh University Press, 2017) and Music/Video: Histories, Aesthetics, Media (Bloomsbury, 2017). Kooijman is the author of Fabricating the Absolute Fake: America in Contemporary Pop Culture (Amsterdam University Press, 2013), editor of the European Journal of Cultural Studies, and co-founding editor of NECSUS: European Journal of Media Studies.

50 Grieteke Meerman, 'Het einde van een tijdperk,' Spits, 5 November 2010; Monique Brandt, 'Internet killed the videostar,' De Stentor, 5 November 2010; Marleen Luijt, 'Wat TMF draaide, hoorde je daarna op de radio,' NRC.NEXT, 5 November 2010; Luuk Kortekaas, 'Als scholier fietste je voor TMF extra snel naar huis,' Algemeen Dagblad, 5 November 2010.

51 Joël Broekaert, 'Er klinkt muziek op tv, achter de decoder,' NRC Handelsblad, April 13, 2011.

52 'Nieuwe TMF wordt digitale jukebox,' Leeuwarder Courant, November 5, 2010. Translation mine. 